\title{
THE TREASURY'S PROPOSAL TO TAX EMPLOYEE'S BARGAIN PURCHASES: T.D. 5507
}

ON April 12, 1946 the Treasury promulgated T.D. $5507^{1}$ which establishes, in effect, a conclusive presumption that all bargain purchases by an employee from his employer result in a differential "in the nature of compensation." As compensation, a differential between the bargain price and the market value of the property-usually stock ${ }^{2}$ in the corporate employer-is taxable income in the year when the purchase is made. Such a purchase is often effected by the exercise of an option granted gratuitously, perhaps in some previous year.

A typical situation to which T.D. 5507 would apply is the case of James M. Lamond. ${ }^{3}$ Induced by an option to purchase up to $25 \%$ of its stock at $\$ 100$ a share, Lamond had become vice-president, treasurer, and general manager of a corporation formed to develop his original manufacturing process. By exercising this option at each increase in capitalization, Lamond could and apparently did maintain his proportionate interest and his influence on corporate policy. In 1941 he thus acquired stock worth $\$ 200$ per share. The Tax Court held that the difference between the $\$ 200$ market value and the $\$ 100$ option price of the stock was not immediately taxable as compensation ${ }^{4}$ because it did not conform to a judicial construction of $\$ 22$ (a) which held that only benefits intended as compensation might be taxed as such. ${ }^{5}$

The courts have not made clear just what facts give rise to a finding of intent to compensate. ${ }^{6}$ The cases are in accord, however, that if, as in the Lamond situation, the option is granted merely to give the employee an added proprietary interest in his work in the hope of stimulating greater

1. Amending U. S. Treas. Reg. 111, §29.22(a)-1 (1943) which interprets INT. REv. CODE, $\$ 22(a)$ (1939) requiring the taxation of "compensation . . . in whatever form paid. . . ."

2. Bargain purchases of items other than corporate stock, while within the purview of both past and present Regulations, seem to have little practical importance.

3. P-H 1946 TC Mess. DeC. SERv. If 46,023 (1946).

4. The effect of T.D. 5507 would be to tax this difference as income.

5. The employment relation per se was held insufficient to make the bargain differential taxable. Hawke v. Commissioner, 109 F. (2d) 946 (C. C. A. 9th, 1940); Salvage v. Commissioner, 76 F. (2d) 112 (C. C. A. 2d, 1935). See Commissioner v. Van Vorst, 59 F. 2d 677 (C. C. A. 9th, 1932), Taplin v. Commissioner, 41 F. (2d) 454 (C. C. A. 6th, 1930). The decisions which uphold the taxation of differentials between market and bargain prices all contain findings that the option was received by way of compensation for services. Commissioner v. Smith, 324 U. S. 177 (1945). Connolly's Estate v. Commissioner, 135 F. (2d), 64 (C. C. A. 6th, 1943). Albert Russell Erskine, 26 B. T. A. 147 (1932).

6. For elaborate analyses of the many factors to which the courts have looked in deciding whether an option was given with this intent, see Sax, Stock Options (1945) 23 TAXEs 505; Bastedo, Taxing Employees on Slock Purchases (1941) 41 Col. L. REv. 239. The futility of this task has occasioned pleas for "objective criteria." Atlas, Toward a Concepl of Compensation (1946) 2 TAX L. Rev. 85; Ferrall, Employee Stock Options and the Smilh Case (1945) 1 TAX L. REV. 225. 
efforts for the company, then the form of the transaction controls, i.e., the excess of value over price is not classified as compensation but as arising out of a mere purchase. ${ }^{7}$

As a purchase, the only effect of this advantageous transaction on the employee's tax position is that the low cost of the stock increases the capital gain realized when, if ever, the stock is sold by the employee. ${ }^{8}$ This treatment has proved very lenient because (1) many employee-stockholders hold their bargain shares as permanent investments and instruments of corporate control and pay no tax for an indefinite period; (2) if the stock is not sold until after the purchaser's death, the differential between cost and value at death is excluded from any capital gain that may be realized upon sale by the legatee or next of $\mathrm{kin}^{9}{ }^{9}$ and (3) the stockholder is able to time the taking of a capital gain for his own tax advantage and need pay no more than the flat $25 \%$ maximum rate on long term gains.

Viewed against this background, T.D. 5507 appears as a radical change. It reads:

"If property is transferred by employer to employee for an amount less than fair market value, regardless of whether the transaction is in the form of a sale or exchange, the difference between the amount paid for the property and the amount of its fair market value is in the nature of compensation and shall be included in the gross income of the employee." 10

The language of this amendment would seem to mean that the Treasury is attempting to tax the exercise of all options by employees. ${ }^{11}$ This in effect makes irrelevant an intent to compensate.

7. Delbert B. Geeseman, 38 B. T. A. 258 (1938) states the rule definitively. See also James M. Lamond, cited supra note 3. Clarence L. Landon, P-H 1943 TC MIEs. DEC. SERv. \ 43,019 (1943); Herbert H. Springford, 41 B. T. A. 1001 (1940); Charles E. Adams, 39 B. T. A. 387 (1939); Omaha National Bank v. Commissioner, 75 F. (2d) 434 (C. C. A. 8 th, 1935).

8. If the differential between the amount the employee paid and the fair market value constitutes additional compensation, the basis for computing capital gains is fair market value on the date the stock was acquired. If the transaction is treated as a purchase, the basis is, of course, simply the amount paid by the employee. Hawlse v. Commissioner, 109 F. 2d 946 (C. C. A. 9th, 1940).

9. Thus, if the employee pays an option price of $\$ 25$ per share, the market value at the time of the employee's death is $\$ 35$ per share, and the legatee sells at $\$ 40$ per share, only the $\$ 5$ increase in value after death is capital gain and the $\$ 10$ increase in value before death escapes taxation altogether. INT. REv. CODE, $\S 113$ (a) (5) (1939).

10. T.D. 5507, 1946 INT. REv. Butr. No. 8 at 2 (1946). The Amendment applies only to options granted after February 26, 1945, the date of the Supreme Court's decision in Commissioner v. Smith, 324 U. S. 177 (1945), I.T. 3795, 1946 Irr. REv. Burl. No. 8 at 3 (1946). It was foreshadowed by the ruling of the Commissioner for salary stabilization purposes. Mim.S.S.U. No. 65, 1 CCH 1946 FED. TAX REP. I 53.105.

11. As early as 1923, T. D. 3455, II-1 Coss. BuLL. 50, proposed that "Where property is sold by a corporation to a shareholder or member, or by an employer to an employee, for an amount substantially less than its fair market value, such shareholder or member of the 
This administrative departure from the prior, more lenient treatment of these transactions has evoked vigorous criticism ${ }^{12}$ and demands for Congressional action to overrule it. ${ }^{13}$ The legal periodicals have described fully the past history of this problem in the courts; ${ }^{14}$ it is now appropriate to appraise the Treasury's proposed solution from an economic as well as a legal point of view.

\section{The "Realization" Argument Against T.D. 5507}

The principal legal argument which may be expected in opposition to T.D. 5507 is that a purchase of property for less than its real worth is an "open transaction," taxable benefit not being recognized until the transaction is "closed" by resale, when a capital gain is "realized." 15 The courts have recognized an exception to this "closed transaction" or "realization" principle in purchases at an artificially low price which employees may be allowed to make in lieu of all or part of their regular cash salary. In this situation the operation of the "realization" rule is suspended by $\$ 22(\mathrm{a})$ of the Internal Revenue Code to permit taxation of the unrealized differential between value and cost. Only because the Code defines gross income to include "compensation . . . in whatever form paid" does the substance of the transaction, the fact that it is a payment for services, prevail over the form, which is that of a purchase. But if the transaction is not intended as compensation-and the new amendment's "in the nature of compensation" is much broader than what the courts have usually meant by intended compensation - then it may be argued that the differential is not the "compensation" whereof the Code speaks, and the requirement of "realization" comes back into play to forbid the taxing of an "open" transaction.

This argument may be rebutted in several ways. The requirement of "realization" is justified by ". . . the possibility that a fluctuation in market

corporation or such employee shall include in gross income the difference between the amount paid for the property and the amount of its fair market value." But after the Board of Tax Appeals and the courts restricted this principle to those transactions in which the bargaindifferential was intended either as compensation or as a dividend (see cases cited supro note 5), the Regulation was amended to read: ". . . such . . . employee shall include in gross income the difference between the amount paid for the property and the amount of its fair market value to the extent that such difference is in the nature of . . . compensation for services rendered or to be rendered. . . ." T.D.4879, 1939-1, Cus. BuL.. 159.

12. E.g., Seghers, Stock Purchase Oplions and the New T.D. 5507 (1946) 41 N. Y. CERT. Public Accountant 250.

13. H.R. 5561 was introduced by Representative Madden on Feb. 22, 1946, two months prior to T.D. 5507. Though originally intended to simplify a tangle of case law, the bill has been approved as a legislative countermand of the amended Regulation. Tyler, Slock Options (1946) 24 TAXES 611, 613.

14. Schwenk, Disguised Compensation and Dividends as Taxable Income (1946) 60 HARv. L. Rev. 44; Atlas, supra note 6; Ferrall, supra note 6; Sax, supra note 6; Bastedo, supra note 6.

15. Palmer v. Commissioner, 302 U. S. 63, 69 (1937). 
value will wipe out the differential before a transfer, and the administrative difficulty of determining its existence, ..."10 However, "realization" should not be a fetish but should be required only when one of these two reasons are relevant. In the case of an employee's bargain purchase neither applies. Since the exercise of the option fixes the time for determining both cost and market value, there is no doubt as to either the existence or the amount of the differential. Even before T.D. 5507 any subsequent fluctuations in market value were taken into account taxwise as a capital gain or loss when and if the stock was finally sold by the employee. ${ }^{17}$ This functional approach to "realization" is implicit in some of the later stock dividend cases ${ }^{18}$ which have required the payment of taxes on "realizable" as well as "realized" income. Such an interpretation recognizes that the realization criterion is no more than a standard of convenience which uncertainties of valuation forced the courts to engraft ${ }^{19}$ upon the economist's definition of taxable income. ${ }^{20}$

Even in this dilute form, "realization" has been involed in support of the contention that employees ought not to be taxed upon the acquisition of stock but only upon its resale, since only then has the cash required to pay it been realized.21 But it would seem neither unreasonable nor impractical that the favored employee be required to sell a little of his nevly-acquired stock to pay the tax on its receipt-or, if he wishes to retain his bloc intact for voting purposes, that he be required to pay the tax out of other current income or by pledging the shares to raise a loan which could be repaid out of dividends. This is to treat the employee no more harshly than the recipient of many types of stock dividends. ${ }^{22}$

Yet even if the validity of the "realization" doctrine be assumed, T.D. 5507 may be sustained as an exception under the Code's requirement of the

16. Note (1937) 50 HaRv. L. REv. 500, 501. See Eisner v. Niacomber, 252 U. S. 189 (1920); MAGILL, TAXABLe IxcoMre (1945) 140.

17. See note 8 supra.

18. Koshland v. Helvering, 298 U. S. 441 (1936); Helvering v. Gowran, 302 U. S. 238 (1937).

19. "Outright abandonment of the realization criterion would be utter folly; no worl:able scheme can require that taxpayers reappraise and report all their assets annually; . . . Our income taxes, as a matter of declaration, of administration, and of adjudication, rest upon great masses of business records and accounts; and they simply must follow, in the main, the established procedures of accounting practice. Thus, they must follow the realization criterion, but not so blindly and reverently as in the past." Swoxs, Persowar Ixco:re TAXation (1938) 207-8.

20. The classic formulation of the theory of taxable income requires the inclusion of unrealized appreciation. "A scheme of arbitrary apportionment of the gain over the priod of accrual would be infinitely superior to the present practice of taxing gains only when realized." Harg, The Concept of Incone in The Federil Iscose Tax (symposium) (1921) 24. Cf. Seligman, Are Stock Dividends Intome? 9 Axs. Econ. Rev. (1919) 517 and the devastating critique of Seligman's position in Simons, op. cit. supra note 19 at 85-9.

21. Bastedo, supra note 6.

22. See note 18, supra. 
taxation of "compensation ... in whatever form paid." 23 To do this would be no more than to bring the judge-made definition of "compensation" 24 into line with both popular understanding and business practice. The element of intent in this definition stems from conceptions, such as "consideration" and "meeting of the minds" relevant to contract enforcement. But what is relevant for taxation is how much the employee ultimately receives and not how much he could have compelled his employer to pay. The courts have impliedly recognized this by devising that hybrid notion, the bonus taxable as "additional compensation." 25 Thus, the juridical hiatus between "compensation" and "gift" is bridged so as to correspond more adequately to the subtle gradations found in actual experience. To date, however, the courts have not viewed bargain purchases so realistically as bonuses. Yet here, too, the employee's economic position is bettered on a certain date by a measurable amount because of his services to the employer: why should not this be considered "compensation" within the meaning of the Internal Revenue Code?

Equally unrealistic is the application of investment categories, e.g., purchase and "realization," to a transaction which was not entered into for the usual investment motives. Characteristically the company is not trying to raise funds but to improve the "morale" of its officers. ${ }^{26}$ One may well wonder, therefore, why for tax purposes the government should treat as an investment by the employee a corporate device to retain the services of a valued employee and to insure his conscientiousness by making his income dependent upon the prosperity of the business. ${ }^{27}$

23. See INT. Rev. CoDE § 22(a) (1939).

24. See cases cited supra, note 5 .

25. "It is settled law that a payment may be compensation for services although made voluntarily and without legal obligation." Willkie v. Commissioner, $127 \mathrm{~F}$. (2d) 953,955 (C. C. A. 6th, 1942); Fisher v. Commissioner, 59 F. (2d) 192 (C. C. A. 2d, 1932); Weagant v. Bowers, 57 F. (2nd) 679 (C. C. A. 2d, 1932); Lucas v. Ox Fibre Brush Co., 281 U. S. 115 (1930); Old Colony Trust Co. v. Commissioner, 279 U. S. 716 (1929).

26. "When executives secure options they are definitely interested in the future welfare of the company from a different point of view than when they are simply paid a fixed cash salary. . . The assumption is that once the officer became a stockholder he would assume the character of a partner or owner and hold his stock permanently. . . . Still another theory of options, and directly opposed to those mentioned above, is that they are similar to a bonus, or additional compensation, and as such can be disposed of at any time without criticism from other stockholders or officers." Baker, Stock Options for Executives (1940) 19 Harv. Bus. Rev. 106, 121, 108. And see Dillavou, Employee Slock Options (1945) 20 Accounting Rev. 320.

27. The artificiality of the opposite position was early made manifest by the Board of Tax Appeals in the Erskine case: "The petitioner's promise to pay at his own option $\$ 10$ and $\$ 25$ per share, respectively, for the common and preferred shares that had a ready market value of many times those amounts would hardly constitute a fair or adequate consideration to support a contract of purchase and sale." Albert Russell Erskine, 26 B. T. A. 147, 156 (1932).

The argument that the employee merely "desires to invest in the company at the existing market value, and, having insufficient funds, he contracts for the right to purchase later at a price which is at, or near, the market value when he was employed. . . must be 


\section{The Analogy between Bargain Purchases and Gifts}

An offer to sell to an employee stock worth $\$ 25$ for $\$ 20$ looks to the layman strikingly like a bonus or a gift. Some of the cases on the taxability of bonuses and gifts made to employees reveal analogies which support the validity of T.D. 5507 as an attempt to bring the exercise of stock options within the statute as a form of bonus. More specifically, the cases show the criteria used by the courts in distinguishing bonuses, taxable as "additional compensation," from gifts, exempt by virtue of $\$ 22(\mathrm{~b})(3)$ of the Code.

In Bogardus \%. Commissioner of Internal Reienue, ${ }^{28}$ the Unopco Company paid to the taxpayer and other employees of the Universal Company, certain of whose assets it had acquired, sums of money in recognition of their valuable and loyal services to Universal. The two corporations were in no way connected at the time of the distribution, neither the corporations nor their stockholders were under any obligation to pay additional compensation, and the distributions were not made for any service rendered or to be rendered to Unopco or its stockholders. The Supreme Court held that the payments were gifts ${ }^{29}$ but said: "If the disbursements had been made by the Universal company, or by stockholders of that company still interested in its success and in the maintenance of the good will and loyalty of its employees, there might be ground for the inference that they were payments of additional compensation." 30

This dictum was the basis of the decision in Uniled Slates $v$. DuPont.31 There, the DuPont Securities Company granted a bloc of its shares to employees of a subsidiary powder company, pursuant to a resolution of the parent company's directors which read ". . . to recognize the past and encourage the future services of certain of the employees of said Powder Company." The Court found that these shares were not gifts but should have been reported as compensation in the year of receipt. ${ }^{32}$ Thus there would seem to be judicial precedent for the statement that outright transfers of cash or stock made by employers as incentives to employees are not to escape taxation as income by being labeled "gifts." ${ }^{33}$ It is anomalous to exempt similar transactions as "purchases" merely because the employee

discounted severely because the employee does not contract to purchase, but merely obtains an option under which he may purchase the stock if it is profitable for him to do so." Dillavou, supra note 26 , at 321 .

28. 302 U.S. 34 (1937).

29. Justices Brandeis, Stone, Cardozo, and Black dissented.

30. Bogardus v. Commissioner, 302 U. S. 34, 41 (1937). Cf. Helvering v. Ameriean Dental Co., 318 U.S. 322 (1943) in which it was held that a gift was not subject to income tax although it had been made for a business purpose.

31. 47 F. Supp. 894 (D. C. Del. 1942).

32. The government's claim against the taxpayer was dismissed on another ground.

33. Where the incentive factor is absent, as in the cases of honoraria to retiring employees, the payment is usually classified as a non-taxable gift, Cunningham v. Commis sioner, 67 F. (2d) 205 (C. C. A. 3d, 1933) unless the company deducted it as salary espense on its own return, Fisher v. Commissioner, 59 F. (2d) 192 (C. C. A. 2d, 1932) or represented 
makes some contribution to the cost of what he receives. ${ }^{34}$ Yet this is the effect of the decisions ${ }^{35}$ which have held taxable only what the employee was entitled to as payment for his past or future services and not what was given him to induce greater exertions. By eliminating this distinction, T.D. 5507 could be said to do no more than apply to bargain purchases the general standard that an employee may be taxed on receipts of money or property intended to induce more conscientious efforts. ${ }^{36}$ Thus if the DuPont decision is valid, T.D. 5507 no longer appears as a radical departure from all judicial precedent. Instead it ends an unjustified exception to a recognized principle of law.

T.D. 5507 does more, however, than merely substitute a criterion of "intent to afford incentive" for "intent to make compensation." In requiring the taxation of all cut-rate purchases by employees as "in the nature of compensation;" the Amended Regulation adopts an objective standard. It thus removes the basis of the economist's reproach that the state of the employer's mind has no relevance to whether the employee should be taxed on his economic betterment. If there is no substantial difference in the employee's economic position to justify a distinction between "intent to make compensation" and "intent to afford incentive," it follows that, except in so far as may be necessary to negative a gift, ${ }^{37}$ intent should be immaterial.

it to stockholders as compensation, Schumacher v. United States, 55 F. (2nd) 1007 (Ct. Cl. 1932).

34. This principle is equally valid where the benefit is conferred, not by the recipient's employer, but by a third person. "We know of nothing to prevent another than the employer from paying compensation for the employee's services, where, as here, he has a real interest in the services to be performed." John J. Batterman, P-H 1943 TC MEM. DEC. SERv. If 43,098 (1943). See also Schumacher v. United States, 55 F. (2d) 1007, 1011 (Ct. Cl. 1932); Bass v. Hawley, 62 F. (2d) 721 (C. C. A. 5th, 1933). Where the third person is found to have no such interest, the benefit is classified as a gift. Bogardus v. Commis* sioner, 302 U. S. 34 (1937); Jones v. Commissioner, 31 F. (2d) 755, 756 (C. C. A. 3d, 1929).

35. See note 7 supra.

36. A good example of the need for this broader rule is Herbert H. Springford, 41 B. T. A. 1001, 1008 (1940). Here "as further consideration . . . for performing services" the employment contract provided for a series of options but required that Springford be in the employ of Servel at the time of their exercise. Despite this evidence that the company's purpose was to insure Springford's continued services, the BTA disallowed the tax because unable to find a sufficiently clear and definite showing "that a transaction, which in form is nothing more than a purchase . . . is in fact to some extent the payment of compensation for services rendered or to be rendered."

37. INT. REv. CODE $\S 22(\mathrm{~b})(3)$ (1939) requires exemption of gifts. One's material welfare is just as effectively augmented by gratuitous receipts as by earnings from personal services or by the yield of investments. Exemption of a gift from the income tax is justifiable where the transaction is more appropriately taxed by a separate levy. It is submitted that a stock purchase differential should be exempt as a gift only where the stockholders of the employer-corporation have paid a gift tax. INT. REv. CoDE $\$ 1002$ (1939). Despite the difference between income and gift tax rates, the amended regulation should not then apply because taxing as compensation a bona fide gift. 
T.D. 5507 receives further support from the cases classifying outright cash payments as bonuses or gifts. Since it is ordinarily improper for directors to give away corporate assets, the courts have repeatedly denominated as a bonus a payment to an employee in excess of the compensation required by his contract of employment ${ }^{35}$ unless the payment has been approved by the stockholders ${ }^{39}$ who alone may transform a taxable bonus into a tax-free gift. ${ }^{40}$

By analogy these cash bonus cases ${ }^{41}$ indicate that the amount by which the market price at the time the employee buys his stock exceeds the option price should not go free of income tax unless intended as a gift and that in the case of corporations no such intention should be inferred unless the option is denominated a "gift" 12 by the stockholders. ${ }^{13}$ In so far as these conditions are not fulfilled, the courts should sustain the operation of T.D. 5507 .

\section{Exercise Value versus Present Value}

Conceding that an employee's bargain purchase should be taxed as "in the nature of compensation," the taxpayer may nevertheless contest the Treasury's method of measuring compensation. A dictum in Commissioner of Internal Revenue v. John H. Smith ${ }^{44}$ gives support to the argument that the appropriate index of such income may be the present value of the option on the date of receipt, or when first exercisable, rather than the difference between option price and market price at the time the option is actually exercised.

The "present value" might be determined by one method or by a combina-

38. Noel v. Parrott, 15 F. (2d) 669 (C. C. A. 4th, 1926); cited with approval in Old Colony Trust Co. v. Commissioner, 279 U. S. 716 (1928); C. B. Wilcox, 27 B. T. A. 580 (1933); cf. Lunsford v. Commissioner, 62 F. (2d) 740 (C. C. A. 6th, 1933).

39. Bogardus v. Commissioner, 302 U. S. 34 (1937); Blair v. Rosseter, 33 F. (2d) 286 (C. C. A. 9th, 1929); Jones v. Commissioner, 31 F. (2d) 755 (C. C. A. 2d, 1929); cf. Schumacher v. United States, 55 F. (2d) 1007 (Ct. Cl. 1932). The deduction from corporate income taxes which the corporation loses by classifying payments to employees as gifts-or purchases-rather than as additional compensation, thus benefiting the employee tarsirise, may be regarded as a corporate "asset," transfer of which to an employee requires the eanction of the stockholders.

40. This again illustrates the anomalous consequences of determining tazability by the mere denomination of a receipt. However, the gift-bonus distinction may serve another objective by insuring that schemes to benefit corporate officials vill confer no tax advantage until subjected to the vote of the shareholders.

41. See citations in notes 38 and 39 supra.

42. Schumacher v. United States, 55 F. (2d) 1007,1011 (Ct. Cl. 1932).

43. "Popular as well as business opinion concerning options as a form of executive compensation has varied all the way from enthusiasm to complete disapproval, expressed as: 'For executives, options furnish a heads-I-win-tails-you-lose proposition'. . . . The method of informing stockholders . . . varies all the way from a vague footnote on a balance sheet to a complete description of the agreements." Baker, supra note 26, at 106, 116. See Gardener and Forsythe, Stock Purchase Warrants and "Rights" (1931) \& So. Caltr. L. REv. 375.

44. 324 U.S. 177, 181 (1945). 
tion of several. (1) Where option price is less than market price on the day when the option is received (or might first be exercised), this difference could be taxed. But where option price equals or exceeds the market price, a tax could only be levied when the option is actually exercised (the Treas ury's method both before and under T.D. 5507) or not at all-until eventual realization of a capital gain by re-sale of the shares by the employee. Such a bifurcated system would be indefensible. It would treat differently persons who have benefitted equally by the exercise of the option, needlessly complicate the tax law and invite avoidance. ${ }^{45}$ (2) Where a third party makes the employee a bona fide offer for the option, this offer might be evidence of the option's "present value." But this approach affords no solution where no such offer can be shown. (3) The present value of an option on receipt, particularly where non-assignable, might be established by the testimony of responsible financial experts. This method, however, unlike the Treasury's simple arithmetic differential, would invite valuation controversy.

Besides difficulties of measurement, "present value" might raise a vexatious question of intent. In the Smith case Chief Justice Stone said: "When the option price is less than the market price of the property for the purchase of which the option is given, it may have present value" and the option itself, rather than the proceeds of its exercise "might be found to be the only intended compensation." 46

If this rationale were followed, how would the Treasury and the courts decide whether the employer intended as compensation the "present value" or the value of the option when exercised? To invoke intent to determine the extent of compensation is to invite a whole new set of intricate rules paralleling the confusing standards for determining the existence of compensation. ${ }^{47}$ Before the "exercise value" measure of compensation used continuously since $1923^{48}$ is disregarded, reasons more persuasive than the employer's intent ${ }^{49}$ should be required. ${ }^{492}$

In favor of "present value" it might be argued that the Trensury's method allows the employee to exercise the option and be taxed on the

45. E.g., the employer could control the tax treatment of the option by setting the option price higher or lower than the market price at the time the option is given.

46. 324 U. S. 177, 181-2 (1945). See Ferrall, supra note 6, at 230. The option might have a small but definite "present value" even when option price originally excecded market price if it was expected that, before the offer lapsed, market price would be greater than option price.

47. See note 6 supra. Instead of the promulgating of "objective criteria" the hunt for the "will-o'-the-wisp" of intent is revived. See Ferrall, sulpra note 14, at 228; Atlas, supra note 14 , at 91 .

48. When T.D. 3455 was promulgated. See note 11 supra.

49. Employer's state of mind is no more relevant to extent of compensation than to its existence. See discussion, pp. 712, supra.

49a. Logic, court decisions, and the duty of corporate officials to their stockholders "demand that the compensation be determined only at the date the option is exercised and the stock issued." Dillavou, supra note 26, at 326. 
transaction in a year in which he has less income from other sources or large deductions. Apparently the Treasury regards such minimizing of taxes as involving a smaller revenue loss than taxing options prematurely. Since the prudent employee does not exercise his option immediately but waits for a rise in market value, the purchase differential is generally greater than the "present value" of the option when first exercisable. Hence it is not surprising that "present value" has often been advocated by taxpayers" only to be successfully opposed by the Treasury. ${ }^{51}$

\section{The Weight to be Accorded a Treasury Regulation}

While T.D. 5507 is justified on its merits as the appropriate way to tax bargain purchases by employees, there remains the question of the weight courts should accord to a Treasury Regulation. Although the Internal Revenue Code authorizes the Treasury to prescribe "all needful rules and regulations" for the enforcement of the income tax, ${ }^{52}$ the courts have long held that Treasury Regulations merely state the Treasury's construction of the statute," which though "entitled to great respect ... cannot be deemed decisive." 54 Commentators, however, have attacked this older view as a "basic myth" ${ }^{55}$ distorting the real problem which is not to discover what Congress intended but to decide how to treat a situation which Congress never contemplated. The proper test of a regulation, then, would be whether it is a "reasonable implementation of the statutory language" is and "not whether the regulation is the most reasonable which could have been devised to suit the occasion." 57

A major objection to the Treasury's newly proposed treatment of bargain

50. Logically, however, the "present value" method requires a tax in the year of the receipt of the option regardless of whether the employee-optionee ever decides to exercise it, since his compensation is then his prospective chance of benefit rather than his actual benefit as determined by hindsight. Hence the employee might have to pay a tax for a privilege which subsequently proved of no use to him.

51. Bothwell v. Commissioner, 77 F. (2d) 35 (C. C. A. 10th, 1935); Phillip W. Haberman, 31 B. T. A. 75, 80-1 (1931); Albert Russell Erskine, 26 B. T. A. 147, 162 (1932). However, the Commissioner of Internal Revenue has approved this method for salary stabilization purposes. $1 \mathrm{CCH} 1946$ FED. TAX REP. I 53,105.

52. INT. REv. CoDE $\$ 62$ (1939).

53. Manhattan Equipment Co. v. Commissioner, 297 U. S. 129, 134 (1936); Hesslein v. Hoey, 91 F. (2d) 954 (C. C. A. 2d, 1937), cert. denied, 302 U. S. 756 (1937); Walker v. United States, 83 F. (2d) 103 (C. C. A. 8th, 1936); cf. Helvering v. Safe Deposit and Trust Co. of Baltimore, 95 F. (2d) 806 (C. C. A. 4th, 1938); see Alvord, Treasury Regulation and the Wilshire Oil Case (1910) 40 CoL. L. Rev. 252, 260-1.

54. Hesslein v. Hoey, 91 F. (2d) 954, 956 (C. C. A. 2d, 1937).

55. Eisenstein, Some Iconoclastic Reflections on Tax Administration (1945) 58 Harv. L. REv. 477, 509. See Griswold, A Summary of the Regulations Problem (1941) 54 HaRv. L. REV. 398.

56. Eisenstein, supra note 55 , at 531 .

57. Id. at 528 . 
purchases is that it flies in the face of two decades of judicial decisions purporting to effectuate Congressional intent. This objection would not be valid under the new philosophy. "Once the courts have construed a statute, it is extremely difficult to justify an administrative departure from the judicial construction, which presumably represents specific Congressional intention. But if a regulation is sustained as a reasonable implementation of a statute, there is no theoretical barrier to sustaining a subsequent and different regulation as also reasonable." 58

A second possible objection is that Congress has reenacted $\S 22(a)$ without relevant changes since 1939, when the Treasury, in effect, incorporated the requirement of intent to compensate into the Regulations. ${ }^{50}$ Congressional re-enactment of a statutory provision has been claimed to imply legislative approval of administrative interpretations. This view was unequivocally rejected by the Supreme Court in Helvering v. Wilshire Oil Co.00 Indeed if administrative flexibility to renovate rules in the light of experience is not to be unduly limited, neither the previous stock option cases nor the "reenactment rule" should prevent the courts from upholding T.D. 5507.61

The Supreme Court has characterized $\S 22(a)$ as "so general in its terms

58. Id. at 536. This position has received the approval of Dean Griswold of tha Harvard Law School: ". . . [W]here the original regulation was contemporaneous, and has been long continued, it may be argued that the factors of certainty and predictability, and a proper regard for the respective functions of legislature and administration, require that the law as thus established should not be subject to change by mere administrative fiat, but that a change, if it is deemed necessary, should be sought from Congress. On the other hand, it may be said that interpretative regulations deal only with the interstitial details of tax law. They are generally matters about which Congress has no very strong views. In the long run, such details can be worked out more adequately by the Commissioner and tho courts than by the Congress." Hence Dean Griswold concludes: "Where the statutory provision is very general and indefinite, such as the definition of gross income, prospective changes in the regulations under it should be allowed as a means of working out the complex concept outlined in the statute." Griswold, supra note 55, at 416.

59. T.D. 4879 . See note 11 supra.

60. "The oft-repeated statement that administrative construction receives legislative approval by re-enactment of the statutory provision, without material change . . . does not mean that a regulation interpreting a provision of one act becomes frozen into another act merely by reenactment of that provision, so that administrative interpretation cannot bo changed prospectively through exercise of appropriate rule-making povers. $C f$. Morrissey v. Commissioner, 296 U. S. 344,355 (1935). The contrary conclusion would not only drastically curtail the scope and materially impair the flexibility of administrative action; it would produce a most awkward situation. Outstanding regulations which had survived one Act could be changed only after a pre-view by Congress." 308 U. S. 90, 100-1 (1939).

61. An alternate rationale for this result was suggested by Justice Frankfurter in Hel. vering v. Hallock, 309 U.S. 106, 121 n. 8 (1940). "Since the Treasury has amended its regulations in an effort to conform administrative practice to the compulsions of the St. Louis Trust cases, it cannot be deemed to have bound itself by this change." But see Surrey, The Scope and Effect of Treasury Regulations under the Income, Estate and Gift Taxes (1940) 88 U. of PA. L. REv. 556, 583. 
as to render an interpretative regulation appropriate." 02 The interpretation given $\S 22$ (a) by T.D. 5507 embodies the recognized principle that by this section Congress has attempted to reach all gains and profits which may be taxed under the Sixteenth Amendment. ${ }^{63}$

Peter Miller $\dagger$

62. Helvering v. Reynolds Tobacco Co., 306 U. S. 110, 114 (1939); Morriscey v. Commissioner, 296 U. S. 344 (1935).

63. Eisner v. Macomber, 252 U. S. 189, 203 (1920); Irwin v. Gavit, 263 U. S. 161, 166 (1925). Comment (1937) 50 Harv. L. Rev. 500.

$\dagger$ Member, Second Year Class, Yale Law School. 